\title{
Le sable du Sahara à la rencontre de la neige
}
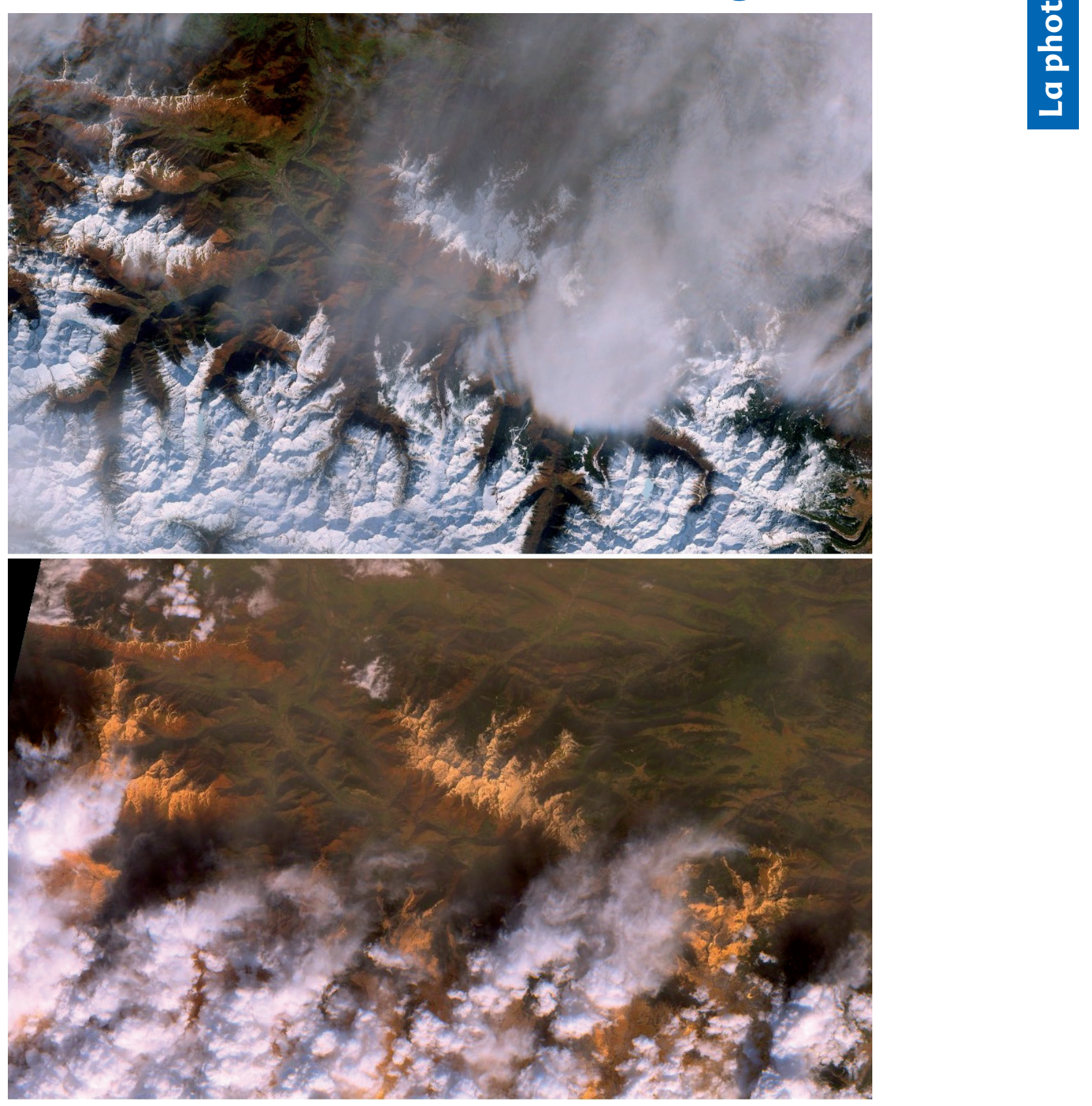

Images en vraies couleurs prises par le satellite Sentinel-2, le 4 février (en haut) et le 6 février 2021 (en bas). Source : Simon Gascoin (Cesbio).

e 6 février au matin, de nombreuses régions du sud et de l'est de la France se - réveillent sous un ciel aux teintes ocres. Il s'agit de panaches de poussières désertiques originaires du Sahara et transportés par les vents jusque sur une grande partie de l'Europe du Sud et de la France. Ce phénomène n'a rien d'exceptionnel, mais son ampleur est cette fois remarquée de tous. Au-delà des couleurs singulières prises par le ciel, le dépôt de poussières est particulièrement spectaculaire en montagne, dans les Alpes ou les Pyrénées, comme ici autour du massif de Tabe (au centre de l'image), proche de la vallée de l'A riège, près de Tarascon (vers la gauche). La neige disparaîtra sous la couche de poussières, quelquefois durant plusieurs jours, jusqu'à ce qu'une nouvelle chute de neige ne la recouvre à son tour. 